\title{
Ficus hispida Bark Extract Prevents Nociception, Inflammation, and CNS Stimulation in Experimental Animal Model
}

\author{
Md. Sariful Islam Howlader, ${ }^{1}$ Md. Afjalus Siraj, ${ }^{1,2}$ Shubhra Kanti Dey, \\ Arpona Hira, ${ }^{1}$ Arif Ahmed, ${ }^{1}$ and Md. Hemayet Hossain ${ }^{3}$ \\ ${ }^{1}$ Pharmacy Discipline, Life Science School, Khulna University, Khulna 9208, Bangladesh \\ ${ }^{2}$ Department of Pharmaceutical Sciences, Daniel K. Inouye College of Pharmacy, University of Hawaii at Hilo, Hilo, HI 96720, USA \\ ${ }^{3}$ BCSIR Laboratories, Bangladesh Council of Scientific and Industrial Research (BCSIR), Dhaka 1205, Bangladesh \\ Correspondence should be addressed to Md. Afjalus Siraj; saeed_2567@yahoo.com
}

Received 28 December 2016; Revised 19 March 2017; Accepted 30 March 2017; Published 12 April 2017

Academic Editor: Olumayokun A. Olajide

Copyright (C) 2017 Md. Sariful Islam Howlader et al. This is an open access article distributed under the Creative Commons Attribution License, which permits unrestricted use, distribution, and reproduction in any medium, provided the original work is properly cited.

\begin{abstract}
Background. Ficus hispida is traditionally used in the ailment of pain, inflammation, and neurological disorders. The present study set out to evaluate the in vivo antinociceptive, anti-inflammatory, and sedative activity of the ethanol extract of Ficus hispida bark (EFHB). Methods. The antinociceptive activity of EFHB was evaluated by using acetic acid induced writhing, formalin, hot plate, and tail immersion methods in Swiss albino mice. Its anti-inflammatory activity was assessed by using carrageenan and histamine induced rat paw oedema test in Wister rats. The central stimulating activity was studied by using pentobarbital induced hypnosis, hole cross, and open field tests in Swiss albino mice. Results. EFHB demonstrated antinociceptive activity both centrally and peripherally. It showed $62.24 \%$ of writhing inhibition. It significantly inhibited licking responses in early (59.29\%) and late phase (71.61\%). It increased the reaction time to the thermal stimulus in both hot plate and tail immersion. It inhibited the inflammation to the extent of $59.49 \%$. A substantial increase in duration of sleep up to $60.80 \mathrm{~min}$ and decrease of locomotion up to 21.70 at $400 \mathrm{mg} / \mathrm{kg}$ were also observed. Conclusion. We found significant dose dependent antinociceptive, anti-inflammatory, and sedative properties of EFHB in experimental animal models.
\end{abstract}

\section{Introduction}

Ficus hispida (Linn.) (Moraceae) is a medium sized tree generally known as Dumoor in Bangladesh. It is a popular plant which is widely distributed throughout subcontinent including India and Bangladesh [1]. Recent publications revealed the presence of several new alkaloids in the twigs, steam-bark, and the leaves of the F. hispida. Twigs contain ficushispimines $\mathrm{A}$ and $\mathrm{B}$ (pyrrolidine alkaloid), ficushispimine $\mathrm{C}$ ( $\omega$-(dimethylamino)caprophenone alkaloid), and ficushispidine (indolizidine alkaloid) whereas hispiloscine (phenanthroindolizidine alkaloid) was isolated from the stem-bark and leaves $[2,3]$. Moreover, the barks of $F$. hispida contain $\beta$-amyrin acetate, $\mathrm{N}$-triacontanyl acetate, lupeol acetate, and 10-ketotetracosyl arachidate [4]. Pharmacological properties of the whole plant, fruit, root, and leaves of $F$. hispida have already been reported. The whole plant has astringent, antidysenteric, antipsoriasis, antianemic, and antihemorrhagic properties [5, 6]. The fruit is edible and acts as a coolant and tonic. A mixture of honey and its juice is a good antihemorrhagic [7]. The roots and leaves are reported for their antidiarrhoeal [8], antidiabetic [9], antibacterial [10], hepatoprotective [11], antioxidant [12], and cardioprotective [13] properties. The leaves and fruits have been also reported for their analgesic activity in acetic acid-induced writhing model in mice [14].

Traditionally in Bangladesh, F. hispida bark is used against pain, inflammation, and neurological disorders such as epilepsy and depression. However, very limited pharmacological investigation was carried out on F. hispida bark till date. Therefore, the present study was designed to explore the in vivo antinociceptive, anti-inflammatory, and sedative activity of $F$. hispida bark. 


\section{Materials and Methods}

2.1. Plant Collection and Extraction. F. hispida barks were collected from the fresh plants from Chittagong district, Bangladesh. The samples were deposited at Bangladesh National Herbarium (BNH) and identified by the experts. A voucher specimen (DACB: 35921) was submitted there for further reference. The barks were shade dried and crushed into powder with the help of Capacitor Start Motor, China. Five hundred grams $(500 \mathrm{~g})$ of bark powder was produced which was transferred into a clean glass vessel and soaked in $1.5 \mathrm{~L}$ of ethanol. The glass vessel was airtight and saved for 7 days at room temperature with random shaking. After 1 week, the mixture was filtered initially by a piece of sterilized cotton material followed by Whatman $24 \mathrm{~cm}$ filter paper (Bibby RE200, Sterilin Ltd., UK) and revised several times to get a very clear filtrate. After that, the ethanol was recovered by using rotary vacuum evaporator (R-205, Buchi, Switzerland) at reduced pressure. The ethanol extract was then dried with the help of SpeedVac (RVT4104, Thermo Scientific). It yielded a $66 \mathrm{~g}$ of gummy concentrate $(13.20 \%)$ crude ethanol extract.

2.2. Chemicals and Drugs. Diclofenac sodium, morphine sulphate, naloxone, carrageenan, histamine phosphate, indomethacin, gallic acid, quercetin, pentobarbitone, and FolinCiocalteu phenol reagent were collected from Sigma Chemical Co. (St. Louis, MO, USA). Ethanol and formalin were purchased from E. Merck, Germany. Analytical grade Tween 80 , sodium carbonate, aluminum chloride, and potassium acetate were bought from E. Merck, India, Ltd.

2.3. Test Animals. For laboratory animal studies, Swiss albino mice (20-25 g) and Wister rats (175-202 g) of both sexes were used. These animals were collected from the animal research branch of International Center for Diarrheal Disease Research, Bangladesh (ICDDR, B). They were kept under standard laboratory environments maintained at $25 \pm 2{ }^{\circ} \mathrm{C}$ and under 12/12 h light/dark cycle and fed with standard diet and water ad libitum during adaptation period. The animals were put away from any food/water overnight before the experiments. During the experimental period, these animals were treated according to the "Ethical Principles and Guidelines for Scientific Experiments on Animals (1995)" formulated by the Swiss Academy of Medical Sciences and the Swiss Academy of Sciences. The experimental procedure was approved by the Bangladesh Council of Scientific and Industrial Research (BCSIR) ethics committee (BCSIR/IAEC/08/11-12).

2.4. Phytochemical Screening. Phytochemical screening of EFHB was carried out by using standard quantitative procedures to investigate the presence of alkaloid, steroid, reducing sugar, saponin, tannin, and flavonoid $[15,16]$.

2.5. Determination of Total Phenolic Content. Total phenolic content of EFHB was determined by modified FolinCiocalteu method [17]. $1 \mathrm{mg} / \mathrm{ml}$ of EFHB was added with the mixture of Folin-Ciocalteu reagent $(5 \mathrm{ml})$ and $75 \mathrm{~g} / \mathrm{l}$ of $\mathrm{Na}$ carbonate solution $(4 \mathrm{ml})$. The combination was kept at $37^{\circ} \mathrm{C}$ for half an hour and the absorbance was measured by UV spectrophotometer at $765 \mathrm{~nm}$ (analytikjena, Model 205, Germany). Finally, total phenolic content was calculated (mg of gallic acid/g of dry extract) by using the standard gallic acid calibration curve equation: $y=6.2548 x-0.0925$ and $R^{2}=0.9962$.

2.6. Determination of Total Flavonoid Content. Total flavonoid content of EFHB was determined by $\mathrm{AlCl}_{3}$ colorimetric method [18]. EFHB was mixed properly with the combination of methanol $(1.5 \mathrm{ml}), 10 \%$ aluminum chloride $(0.1 \mathrm{ml}), 1 \mathrm{M}$ potassium acetate $(0.1 \mathrm{ml})$, and distilled water $(2.8 \mathrm{ml})$. It was then kept at $37^{\circ} \mathrm{C}$ for half an hour. The absorbance was measured by UV spectrophotometer at $415 \mathrm{~nm}$ (analytikjena, Model 205, Germany). Finally, total flavonoids content was calculated ( $\mathrm{mg} / \mathrm{g}$ of quercetin equivalent) by using the quercetin calibration curve equation: $y=4.7385 x+0.0355$ and $R^{2}=0.9993$.

2.7. Acute Toxicity Test. Acute toxicity test of EFHB was investigated in order to determine the dose(s) to be used in different tests in the laboratory animals. Rats were kept in fasting condition for $16 \mathrm{~h}$. 500, 1000, 2000, 3000, and $4000 \mathrm{mg} / \mathrm{kg}$ EFHB dose were orally administered to fasting rats. After that, they were allowed free access to food and water and all the rats were under careful observation over a period of $72 \mathrm{~h}$ and the number of deaths within this period was recorded [19].

\subsection{Antinociceptive Tests}

2.8.1. Acetic Acid-Induced Writhing Test. In the acetic acidinduced writhing model in mice, different groups of animals (five mice/group, total twenty-five) were treated with $1 \%$ Tween 80 in normal saline $(10 \mathrm{ml} / \mathrm{kg}$, p.o.), EFHB $(100,200$, and $400 \mathrm{mg} / \mathrm{kg}$, p.o.), and diclofenac sodium (25 mg/kg, i.p.) $30 \mathrm{~min}$ before intraperitoneal injection of $0.7 \%$ acetic acid. After an interval of $5 \mathrm{~min}$, writhing (constriction of the abdomen, turning of trunk, and extension of hind legs) was observed for $10 \mathrm{~min}[20,21]$.

2.8.2. Formalin Test. In the formalin-induced paw licking test in mice, overnight fasted animals (five mice/group, total thirty) were treated with $1 \%$ Tween 80 in normal saline (10 ml/kg, p.o.), EFHB (100, 200, and $400 \mathrm{mg} / \mathrm{kg}$, p.o.), morphine $(5 \mathrm{mg} / \mathrm{kg}$, s.c.), and diclofenac- $\mathrm{Na}(25 \mathrm{mg} / \mathrm{kg}$, s.c.). Formalin $(20 \mu \mathrm{l}$ of $1 \%$ solution) was injected subcutaneously into the right hind paw of each mouse after $60 \mathrm{~min}$ in oral administered group and after $30 \mathrm{~min}$ in subcutaneous group. Licking or biting of the treated paw was recorded as nociceptive response for $0-5 \mathrm{~min}$ in the early phase and for 15-30 $\mathrm{min}$ in the late phase after formalin injection $[22,23]$.

2.8.3. Hot Plate Test. In this assay, mice were placed on a heated $\left(50 \pm 0.05^{\circ} \mathrm{C}\right)$ metal plate and the time elapsed until the appearance of reactions (lifting or licking of the paws) to the thermal stimulus was recorded as an index of nociception $[24,25]$. A cut-off period of $30 \mathrm{~s}$ was imposed to avoid tissue damage to the paws. Twenty-five mice were divided into 
five equal groups (5 mice/group), which were pretreated with $1 \%$ Tween 80 in normal saline $(10 \mathrm{ml} / \mathrm{kg}$, p.o.), EFHB (100, 200, and $400 \mathrm{mg} / \mathrm{kg}$, p.o.), and morphine ( $5 \mathrm{mg} / \mathrm{kg}$, s.c). The response time was noted at different time intervals, that is, 0 , $30,60,90$, and $120 \mathrm{~min}$. In another set of experiments (total 25 mice; 5 mice/group), an opioid nonselective antagonist naloxone $(2 \mathrm{mg} / \mathrm{kg}$ ) was injected (i.p.) $15 \mathrm{~min}$ prior to the administration of either morphine $(10 \mathrm{mg} / \mathrm{kg}$, s.c.) or $\operatorname{EFHB}(100,200$, and $400 \mathrm{mg} / \mathrm{kg}$, p.o.). Antinociceptive activity was expressed as the increase in latency time to thermal stimulus with respect to control.

2.8.4. Tail Immersion Test. In this experiments, twenty-five mice were homogeneously divided into five different groups where mice tails $(2 \mathrm{~cm})$ pretreated with $1 \%$ Tween- 80 in normal saline (10 ml/kg, p.o.), EFHB (100, 200, and $400 \mathrm{mg} / \mathrm{kg}$, p.o.), and morphine ( $5 \mathrm{mg} / \mathrm{kg}$, s.c.) were immersed in warm water $\left(55 \pm 1^{\circ} \mathrm{C}\right)$. The latency between tail submersion and deflection of the tail was recorded and the pretreatment latency was recorded at 30,60, 90, and $120 \mathrm{~min}$. This latency period was taken as the index of antinociception. Moreover, an opioid nonselective antagonist naloxone $(2 \mathrm{mg} / \mathrm{kg})$ was injected (i.p.) in 25 other mice ( 5 mice/group) in 15 min prior to the administration of either morphine $(10 \mathrm{mg} / \mathrm{kg}$, s.c. $)$ or EFHB and observed as explained above [26].

\subsection{Anti-Inflammatory Tests}

2.9.1. Carrageenan-Induced Oedema Test. Carrageenaninduced rat hind paw oedema was used as the animal model of acute inflammation. In this experiment, twenty-five rats divided into five groups (five rats/group) were treated with $1 \%$ Tween 80 in normal saline $(10 \mathrm{ml} / \mathrm{kg}$, p.o.); EFHB $(100,200$, and $400 \mathrm{mg} / \mathrm{kg}$, p.o.); and indomethacin (10 mg/kg, p.o.). Acute inflammation was induced in groups by subplantar injection of $0.1 \mathrm{ml}$ of carrageenan (1\% suspension in Tween 80 ) in the right paw of rats 1 hour after all of the oral administration. The paw oedema volume was measured with micrometer screw gauze at $1,2,3,4$, and $5 \mathrm{~h}$ after the administration of the tested materials $[27,28]$.
2.9.2. Histamine-Induced Oedema Test. In this experiment, after dividing twenty-five rats into five groups (five rats/group), they were treated with $1 \%$ Tween 80 in normal saline (10 ml/kg, p.o.), EFHB (100, 200, and $400 \mathrm{mg} / \mathrm{kg}$, p.o.), and indomethacin $(10 \mathrm{mg} / \mathrm{kg}$, p.o.). Acute inflammation was induced by subplantar injection of $0.1 \mathrm{ml}$ of histamine with $1 \%$ suspension in Tween-80 in the right hind paw of the rats 30 min after the oral administration of the tested materials. The paw volume was measured with micrometer screw gauze at $1,2,3,4$, and $5 \mathrm{~h}$ after the administration of the tested materials [29].

\subsection{Neuropharmacological Tests}

2.10.1. Pentobarbital Induced Hypnosis. In pentobarbital induced hypnosis test, twenty-five mice divided into five groups (five rats/group) were treated with $1 \%$ Tween 80 in normal saline $(10 \mathrm{ml} / \mathrm{kg})$, EFHB $(100,200$, and $400 \mathrm{mg} / \mathrm{kg})$, and diazepam $(1 \mathrm{mg} / \mathrm{kg})$. Each mouse was placed in a quadrangular observation box $\left(36 \times 36 \mathrm{~cm}^{2}\right)$. After $30 \mathrm{~min}$, pentobarbitone $(40 \mathrm{mg} / \mathrm{kg}$ ) was given to mice to induce sleep. The total sleeping time was monitored for all experimental groups. Mice were observed for the duration of sleep (i.e., time difference between the loss and recovery of reflex) and the latent period (i.e., time difference between pentobarbitone administration and loss of reflex) [30].

2.10.2. Open Field Test. Open field experimental method is routinely used to evaluate emotional and locomotors activities in rodents [31]. A specially designed experimental box was used for this test which had a series of alternatively colored black and white square floor. Five groups containing five mice/group (total twenty-five mice) were treated with $1 \%$ Tween 80 in normal saline $(10 \mathrm{ml} / \mathrm{kg})$, EFHB $(100,200$, and $400 \mathrm{mg} / \mathrm{kg})$, and diazepam $(1 \mathrm{mg} / \mathrm{kg})$. After the treatment, the number of squares traveled by the mice was monitored for 3 min. Percentage inhibition of movements was determined by using the following formula:

$$
\% \text { movement inhibition }=\frac{\{\text { Mean number of movement }(\text { control })-\text { mean number of movement }(\text { test })\}}{\text { Mean number of movements }(\text { control })} \times 100 .
$$

2.10.3. Hole Cross Test. Hole cross experimental method was run in a cage $(L \times W \times H=30 \times 20 \times 14 \mathrm{~cm})$ containing a fix steel partition in the middle [32]. A $3 \mathrm{~cm}$ diameter hole was made at a height of $7.5 \mathrm{~cm}$ in the center of the cage. 25 mice were divided into five groups equally. The different groups of animals were administered with $1 \%$ Tween 80 in normal saline $(10 \mathrm{ml} / \mathrm{kg})$, EFHB (100, 200, and $400 \mathrm{mg} / \mathrm{kg})$, and diazepam $(1 \mathrm{mg} / \mathrm{kg})$. Pain stimulus was produced by placing the animals on hot plate maintained at the temperature of $55 \pm$ $0.5^{\circ} \mathrm{C}$. Paw licking or jumping off the plate was considered as response to pain stimulus. Reaction time for each group was recorded at $0,30,60,90$, and 120 min during the observation period. The number of movements of mice through the hole from one chamber to another was counted after oral administration of tested materials. Percentage inhibition of movements was determined by using (1).

2.11. Statistical Analysis. All of the experimental results are reported as mean \pm SEM. Statistical analysis was performed using one-way analysis of variance (ANOVA) followed by Dunnett's test [33] using SPSS 11.5 software. Differences between groups were considered significant at a level of $p<$ 0.05 . 
TABLE 1: Total phenolic and flavonoids content of EFHB.

\begin{tabular}{lcc}
\hline Treatment & $\begin{array}{c}\text { Total phenolic content } \\
\text { (mg of gallic acid per g of dry extract) }\end{array}$ & $\begin{array}{c}\text { Total flavonoids content } \\
\text { (mg of quercetin per g of dry extract) }\end{array}$ \\
\hline EFHB & $258.37 \pm 6.68$ & $144.29 \pm 7.89$ \\
\hline
\end{tabular}

Here, each value is presented as the mean $\pm \operatorname{SEM}(n=3)$. EFHB $=$ ethanol extract of Ficus hispida barks.

TABLE 2: Effects of EFHB on acetic acid-induced writhing test in mice.

\begin{tabular}{lccc}
\hline Treatment & Dose $(\mathrm{mg} / \mathrm{kg}$, p.o. $)$ & Number of writhes & Inhibition $(\%)$ \\
\hline Vehicle & $10(\mathrm{ml} / \mathrm{kg})$ & $14.3 \pm 0.79$ & - \\
Diclofenac sodium & 25 & $3.5 \pm 0.38^{* *}$ & 75.52 \\
EFHB & 100 & $8.9 \pm 0.45^{*}$ & 37.76 \\
EFHB & 200 & $7.1 \pm 0.36^{* *}$ & 50.35 \\
EFHB & 400 & $5.4 \pm 0.63^{* *}$ & 62.24 \\
\hline
\end{tabular}

Here, each value is presented as the mean \pm SEM $(n=5)$. EFHB = ethanol extract of Ficus hispida.

** Indicating $p<0.01$ compared with control group (Dunnett's test).

* Indicating $p<0.001$ compared with control group (Dunnett's test).

TABLE 3: Effects of EFHB on formalin-induced paw licking test in mice.

\begin{tabular}{|c|c|c|c|c|c|}
\hline \multirow{2}{*}{ Treatment } & \multirow{2}{*}{ Dose (mg/kg) } & \multicolumn{4}{|c|}{ Licking of the hind paw } \\
\hline & & Early phase $(0-5 \mathrm{~min})$ & $\%$ inhibition & Late phase $(15-30 \mathrm{~min})$ & $\%$ inhibition \\
\hline Vehicle & $10(\mathrm{ml} / \mathrm{kg})$ & $98.50 \pm 4.27$ & - & $103.20 \pm 4.93$ & - \\
\hline Morphine & 5 & $28.80 \pm 2.92^{*}$ & 70.76 & $0.90 \pm 0.11$ & 99.89 \\
\hline Diclofenac sodium & 10 & $62.20 \pm 3.85^{* *}$ & 36.85 & $3.80 \pm 0.57^{* *}$ & 96.25 \\
\hline EFHB & 100 & $54.60 \pm 3.31^{*}$ & 44.46 & $49.90 \pm 2.88^{*}$ & 51.64 \\
\hline EFHB & 200 & $48.90 \pm 2.54^{*}$ & 50.36 & $41.10 \pm 4.17^{* *}$ & 60.17 \\
\hline EFHB & 400 & $40.10 \pm 3.22^{*}$ & 59.29 & $29.30 \pm 3.92^{* *}$ & 71.61 \\
\hline
\end{tabular}

Here, each value is presented as the mean $\pm \operatorname{SEM}(n=5)$. EFHB = ethanol extract of Ficus hispida.

** Indicating $p<0.01$ compared with control group (Dunnett's test).

* Indicating $p<0.001$ compared with control group (Dunnett's test).

\section{Results}

\subsection{Antinociceptive Tests}

3.1.1. Acetic Acid-Induced Writhing in Mice. At 100, 200, and $400 \mathrm{mg} / \mathrm{kg}$ EFHB showed 37.76, 50.35, and 62.24 percentage of writhing episode inhibition, respectively. Standard drug diclofenac sodium $(25 \mathrm{mg} / \mathrm{kg})$ showed $75.52 \%(p<0.001)$ reduction (Table 2 ).

3.1.2. Formalin Test. EFHB demonstrated significant inhibition of licking responses in early $(44.57 \%, 50.36 \%$, and $59.29 \%)$ and late phase $(51.64 \%, 60.17 \%$, and $71.61 \%)$ at the doses of 100, 200, and $400 \mathrm{mg} / \mathrm{kg}$, respectively. Standard morphine produced marked inhibition in both the early phase $(70.76 \%)$ and late phase $(99.13 \%)$ whereas diclofenac sodium produced inhibition of licking responses (96.32\%) in the late phase only (Table 3).

3.1.3. Hot Plate Test. EFHB significantly increased the reaction time to the thermal stimulus in a dose dependent manner (3.91, 3.97, and $5.13 \mathrm{~s}$ after $120 \mathrm{~min}$ at 100, 200, and $400 \mathrm{mg} / \mathrm{kg}$, resp.) which was comparable to the standard drug morphine $(5.27 \mathrm{~s}$ after $120 \mathrm{~min})$. Naloxone produced a substantial antagonistic effect on the antinociceptive activity of both EFHB and morphine (Table 4).

3.1.4. Tail Immersion Test. EFHB substantially increased the latency period to hot-water induced thermal stimuli (3.71, 4.52 , and $5.26 \mathrm{~s}$ after $120 \mathrm{~min}$ at 100, 200, and $400 \mathrm{mg} / \mathrm{kg}$ dose) whereas standard drug morphine at $5 \mathrm{mg} / \mathrm{kg}$ showed $3.74 \mathrm{~s}$ latency period after $120 \mathrm{~min}$. Naloxone counteracts the antinociceptive activity of both EFHB and morphine (Table 5).

\subsection{Anti-Inflammatory Tests}

3.2.1. Carrageenan-Induced Paw Oedema. EFHB showed a significant reduction in the carrageenan-induced paw volume after $5 \mathrm{~h}$ as compared with the control group. EFHB (200 and $400 \mathrm{mg} / \mathrm{kg}$ ) inhibited the inflammation to the extent of $44.94 \%$ and $59.49 \%$ while the reference drug, indomethacin, reduced the inflammation by $67.72 \%$ (Table 6).

3.2.2. Histamine-Induced Paw Oedema. At the higher doses (200 and $400 \mathrm{mg} / \mathrm{kg}$ ), EFHB inhibited the inflammation to the extent of $46.43 \%$ and $60.12 \%$ which was statistically significant $(p<0.05 ; p<0.01)$. Indomethacin reduced the inflammation by $69.64 \%$ (Table 7 ). 


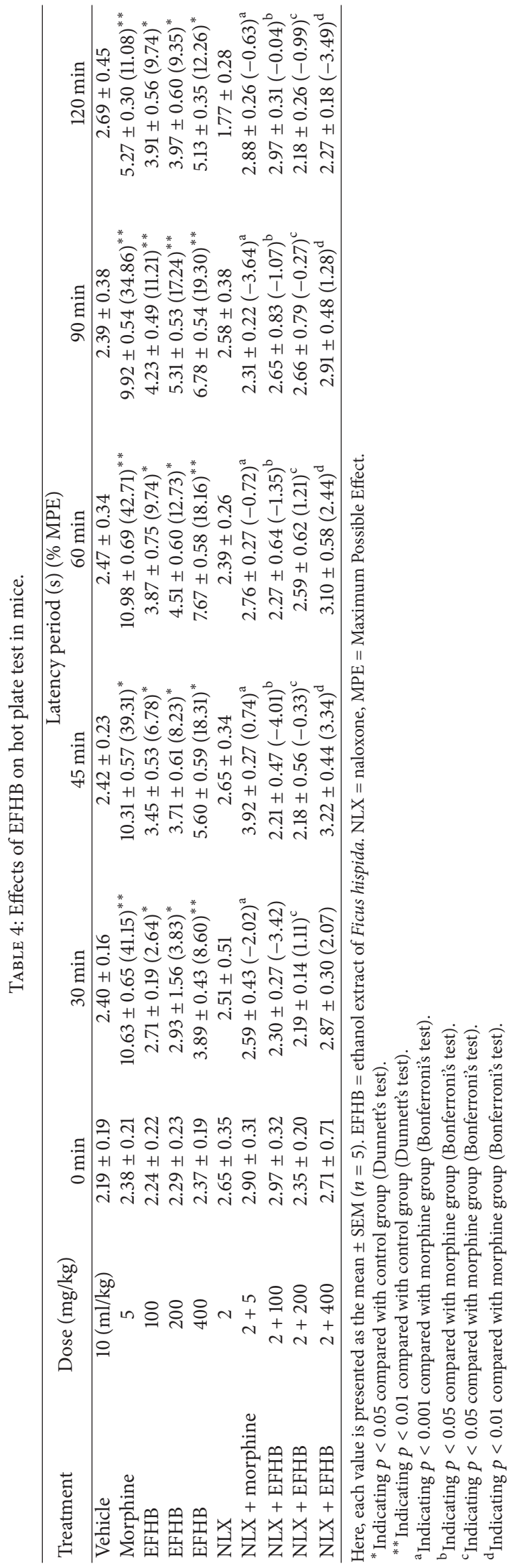




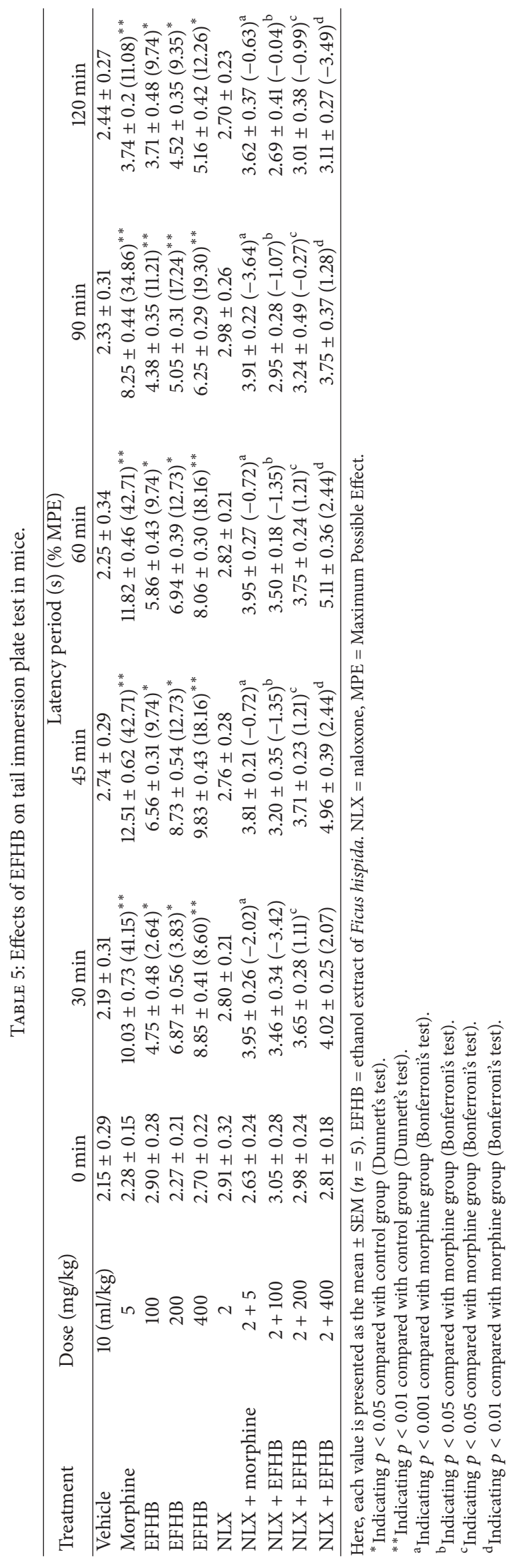




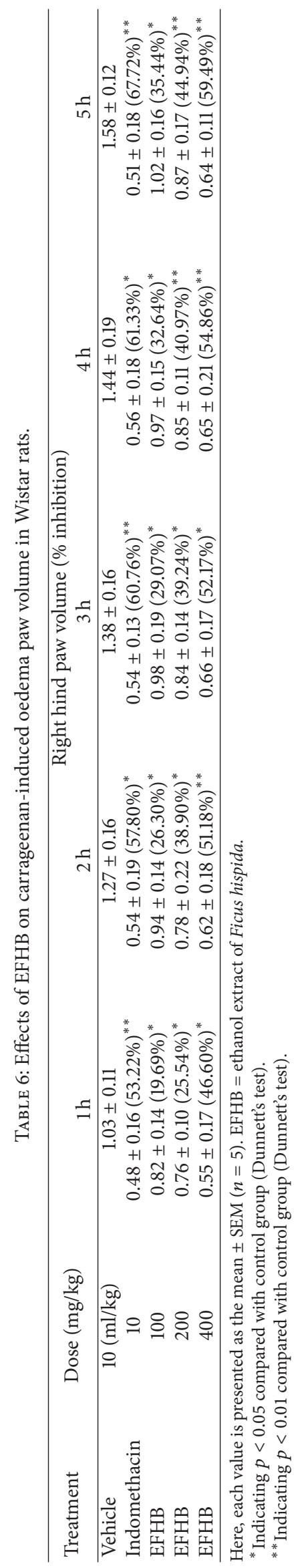




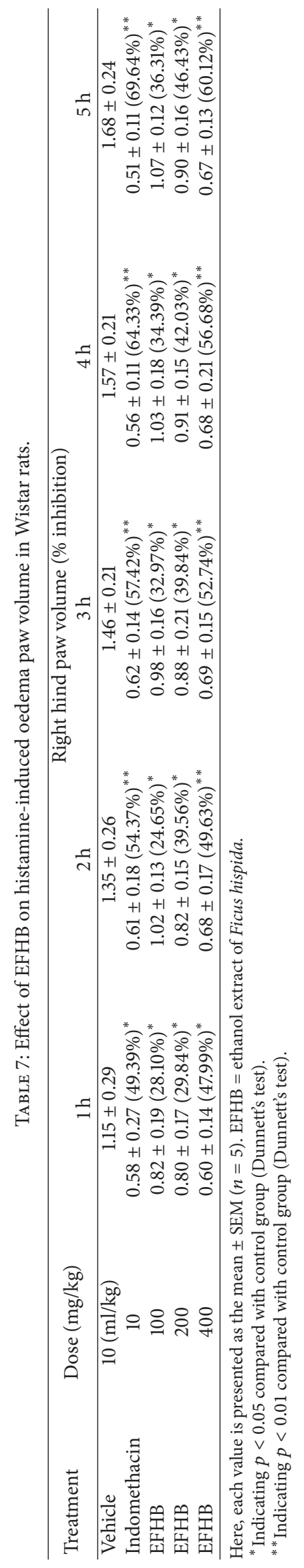


TABLE 8: Effect of EFHB on pentobarbital-induced hypnosis in mice.

\begin{tabular}{lccc}
\hline Treatment & Dose $(\mathrm{mg} / \mathrm{kg})$ & Time of onset of sleep $(\mathrm{min})$ & Total sleeping time $(\mathrm{min})$ \\
\hline Vehicle & $10(\mathrm{ml} / \mathrm{kg})$ & $16.50 \pm 0.81$ & $37.80 \pm 1.13$ \\
Diazepam & 1 (i.p.) & $4.30 \pm 0.16^{* *}$ & $73.50 \pm 2.20^{* *}$ \\
EFHB & 100 & $9.70 \pm 0.57^{* *}$ & $47.90 \pm 1.56^{*}$ \\
EFHB & 200 & $8.20 \pm 0.71^{* *}$ & $53.70 \pm 1.77^{*}$ \\
EFHB & 400 & $7.60 \pm 0.32^{* *}$ & $60.80 \pm 2.01^{* *}$ \\
\hline
\end{tabular}

Here, each value is presented as the mean $\pm \operatorname{SEM}(n=5)$. EFHB $=$ ethanol extract of Ficus hispida.

${ }^{*}$ Indicating $p<0.01$ compared with control group (Dunnett's test).

${ }^{* *}$ Indicating $p<0.001$ compared with control group (Dunnett's test).

\subsection{Neuropharmacological Tests}

3.3.1. Pentobarbital Induced Hypnosis Test. A substantial increase in duration of sleep was observed in the dosages of 200 and $400 \mathrm{mg} / \mathrm{kg}(53.70 \pm 1.77$ and $60.80 \pm 2.01 \mathrm{~min}$, resp., as compared to $73.50 \pm 2.20 \mathrm{~min}$ in the control group at $p<0.001)$ in pentobarbital induced hypnosis test. A notable decrease in onset of action was also showed at the doses of 200 and $400 \mathrm{mg} / \mathrm{kg}$ as compared to the control group. The results were dose dependent and statistically significant $(p<0.001$ and $p<0.01$ ) (Table 8).

3.3.2. Open Field Test. EFHB showed a noticeable decrease in locomotion in the test animals with increasing time. At $240 \mathrm{~min}$, the number of movements was gradually decreased up to $37.50(p<0.01), 30.40(p<0.01)$, and $21.70(p<$ 0.001 ) for the dose of 100,200 , and $400 \mathrm{mg} / \mathrm{kg}$, respectively, whereas movement decreased up to $5.90(p<0.001)$ in case of standard drug diazepam (Table 9).

3.3.3. Hole Cross Test. The EFHB displayed suppression of motor activity and exploratory behavior in the test animal. The locomotor activity lowering effect was evident from the 2nd observation period (30 min) and continued up to 7 th observation period (240 min). At $240 \mathrm{~min}$, number of holes crossed was gradually decreased up to 6.10 ( $p<0.01), 5.20$ $(p<0.01)$, and $4.30(p<0.001)$ for the dose of 100, 200, and $400 \mathrm{mg} / \mathrm{kg}$, respectively. The standard drug, diazepam, decreased the number of holes crossed throughout the observation period (Table 10).

\section{Discussion}

We did not observe any mortality up to the dose of $4 \mathrm{~g} / \mathrm{kg}$ b.w. of EFHB (p.o.) in the test animals which ensured the safety of the experimental dose.

Acetic acid generally produces pain by increasing the level of $\mathrm{PGE}_{2}$ and $\mathrm{PGF}_{2 \alpha}$. It also induces sympathetic nervous system mediators, which were naturally observed at higher level at first $30 \mathrm{~min}$ of injection [34]. It excites pain in nerve endings and activates the production of noxious substances within the peritoneum which generates the writhing response. EFHB exhibited significant dose dependent writhing reduction. This result indicated the peripheral antinociceptive effect of EFHB which may occur due to the inhibition of the synthesis or/and action of prostaglandin. Moreover, as the acetic acid mimics the inflammatory local pain, it may also suggest the probable association of EFHB with the peripheral inhibition of bradykinins and prostanoids [35]. This may be due to the presence of $\beta$-amyrin acetate which is previously reported for its antinociceptive activity [36].

Formalin test was performed since the results of the writhing test alone could not ascertain the source of antinociception. It evaluates antinociceptive property in two distinct phases. In the early/first phase, neurogenic pain is induced by direct chemical stimulation of the sensory afferent fibers; particularly c-fibers. The involvement of substance $\mathrm{P}$ and bradykinin has also been reported. Pain is induced by prostaglandins, histamine, bradykinin, and serotonin in the late phase [37]. Drugs that act on the central nervous system inhibit both phases while peripherally acting drugs inhibit the late phase only [38]. EFHB suppressed the licking time in both phases and appeared effective on both tonic inflammatory and central pain.

The hot plate and tail immersion tests are widely used for assessing central antinociceptive activity. They are distinguished by their tendency to respond to the pain stimuli, as the hot plate demonstrates supraspinal reflex mediated by $\mu_{1}$ and $\mu_{2}$ opioid receptors while the tail immersion monitors a spinal reflex involving $\mu_{2}$ and $\delta$ opioid receptors $[39,40]$. Opioid agents exhibit their analgesic effects both via supraspinal $\left(\kappa_{3}, \mu_{1}, \delta_{1}\right.$, and $\left.\sigma_{2}\right)$ and spinal $\left(\mu_{2}, \delta_{2}\right.$, and $\left.\kappa_{1}\right)$ receptors [39]. In our experiments, EFHB exhibited significant dose dependent but lesser antinociceptive activity than morphine. To verify possible centrally acting antinociceptive mechanism of EFHB, the inhibitory effect of naloxone was carried out. $\mu$ opioid receptor is the major target site for morphine, while naloxone reversed the antinociceptive effect of morphine. Likewise, naloxone also reversed the analgesic response of EFHB against thermal stimuli. This can be explained by the presence of $\beta$-amyrin acetate which is responsible for analgesic effect by vanilloid receptor $\left(\mathrm{TRPV}_{1}\right)$ [41] and also by reducing neuropathic hyperalgesia produced by the direct activation of the cannabinoid receptors [42].

The inflammatory response induced by carrageenan is characterized by a biphasic response with marked oedema formation due to the rapid production of inflammatory mediators. These mediators are subsequently sustained by the release of prostaglandins and nitric oxide which is produced by cyclooxygenase (COX-2) and nitric oxide synthase (iNOS), respectively [43]. EFHB was effective in reducing the oedematogenic response between the 3rd and 5th $\mathrm{h}$ 


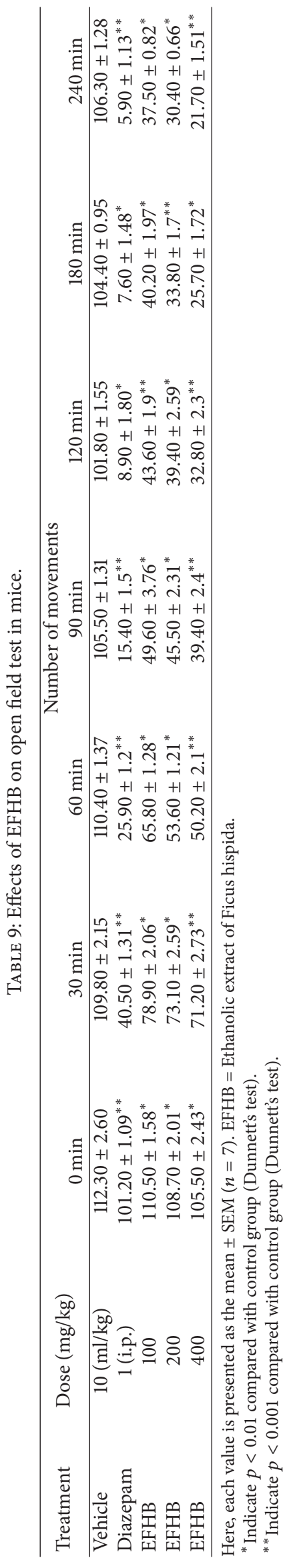




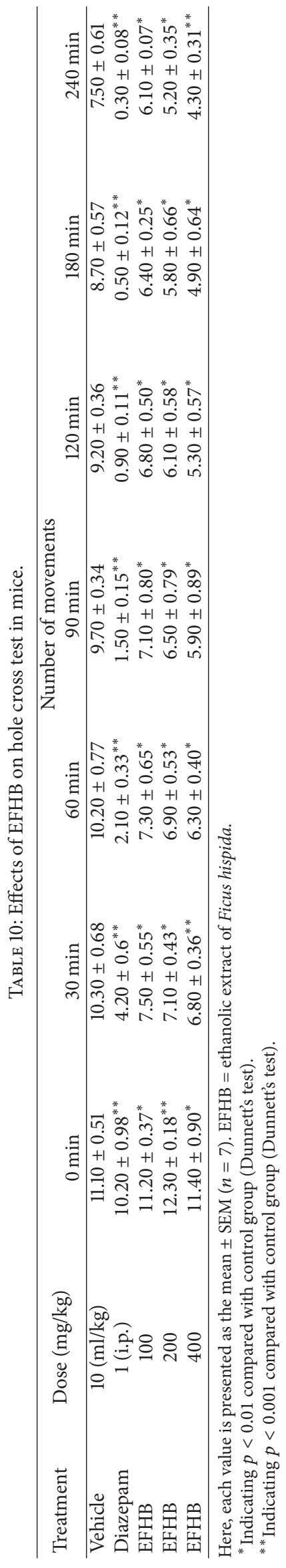


after carrageenan administration signifying that EFHB is able to inhibit one or more intracellular inflammatory signaling pathways. On the other hand, histamine increases the vascular permeability and is known as an important inflammatory mediator [42]. When histamine is subcutaneously injected, it forms a wheal around the injected place due to increase of vascular permeability of the host capillary venules. Substances that antagonize this activity reduce the area. Since EFHB effectively suppressed the oedema in a dose dependent manner, it can be suggested that EFHB exhibited antiinflammatory actions by inhibiting the synthesis or action of histamine. The bark of $F$. hispida contains $\beta$-amyrin acetate which is reported for its anti-inflammatory activity by decreasing IL- $1 \beta$, TNF- $\alpha$, KC, and IL- 6 levels and by inhibiting expression of NF- $\kappa \mathrm{B}$ and COX-2 [44]. It also contains lupeol acetate, which produces anti-inflammatory activity by regulating TNF- $\alpha$ and IL-2 [45]. Moreover, plant derived phenolic and flavonoids often exhibit antioxidant potential [46]. Thus they protect the cells from ROS and generate antiinflammatory activity [47]. In this study, EFHB showed significant amount of phenolic and flavonoid levels and may have been responsible for the potent anti-inflammatory activity recorded (Table 1).

A CNS depressant works either by decreasing the onset or by increasing the duration of sleep or both. EFHB increased the pentobarbitone-induced sedative effect in a dose dependent manner. Barbiturates naturally work on the cerebral cortex to generate their action [48]. EFHB improved sleeping time that can be attributed to its action on the central sleeping mechanism [49]. Moreover, EFHB decreased the locomotor activity which is a parameter of the level of excitability of the CNS [50]. Decrease of locomotor activity is closely related to the depression of the CNS [51]. Sedativehypnotic drugs generate their bioactivity through $\mathrm{GABA}_{\mathrm{A}}$ receptor [52]. EFHB may act by potentiating GABAergic inhibition via membrane hyperpolarization. The sedative activity of EFHB can also be correlated with the presence of $\beta$-amyrin acetate in the F. hispida bark. $\beta$-Amyrin acetate is already reported for its sedative and anxiolytic effects [53]. Furthermore, flavonoids were found to be ligands for the $\mathrm{GABA}_{\mathrm{A}}$ receptor [54]. Tannin, saponin, and glycoside are reported for their sedative effects [55].

\section{Conclusion}

Present study showed potent antinociceptive, anti-inflammatory, and sedative activities of EFHB. All activities were dose dependent and statistically significant. Presence of $\beta$-amyrin acetate, lupeol acetate, and phenolic and flavonoid constituents may play an important role in these bioactivities. We are hopeful that these research findings will definitely provide a rationale for further chemical and biological study on EFHB in the near future.

\section{Disclosure}

The authors are responsible for the writing and contents of the paper.

\section{Conflicts of Interest}

The authors declare no conflicts of interest.

\section{Acknowledgments}

The authors are thankful to BCSIR Laboratories, Bangladesh Council of Scientific and Industrial Research, Dr. Qudrat-EKhuda Road, Dhaka 1205, Bangladesh, for allowing them to use their research facilities.

\section{References}

[1] M. Ripu, I. Kunwar, and W. B. Rainer, "Ficus species in Nepal; a review of diversity and indigenous uses," Journal of Ecology, vol. 11, pp. 85-87, 2006.

[2] Z.-F. Shi, C. Lei, B.-W. Yu, H.-Y. Wang, and A.-J. Hou, "New alkaloids and $\alpha$-glucosidase inhibitory flavonoids from ficus hispida," Chemistry and Biodiversity, vol. 13, no. 4, pp. 445-450, 2016.

[3] V. A. Yap, B.-J. Loong, K.-N. Ting et al., "Hispidacine, an unusual $8,4^{\prime}$-oxyneolignan-alkaloid with vasorelaxant activity, and hispiloscine, an antiproliferative phenanthroindolizidine alkaloid, from Ficus hispida Linn.," Phytochemistry, vol. 109, pp. 96-102, 2015.

[4] P. C. Sharma, M. B. Yelne, and T. J. Dennis, Database on Medicinal Plants Used in Ayurveda, vol. 5, Central Council for Research in Ayurveda and Siddha, New Delhi, India, 2002.

[5] K. M. Nadkarni, Indian Materia Medica, vol. 1, Popular Prakashan, Mumbai, India, 1976.

[6] R. Rastogi and B. N. Mehrotra, Compendium Indian Medicinal Plants, vol. 2, CDRI, Lucknow, Publication and Information Directorate, New Delhi, India, 1993.

[7] S. R. Peraza-Sánchez, H.-B. Chai, G. S. Young et al., "Constituents of the leaves and twigs of Ficus hispida," Planta Medica, vol. 68, no. 2, pp. 186-188, 2002.

[8] S. C. Mandal and C. K. A. Kumar, "Studies on anti-diarrhoeal activity of Ficus hispida. Leaf extract in rats," Fitoterapia, vol. 73, no. 7-8, pp. 663-667, 2002.

[9] R. Ghosh, K. Sharatchandra, S. Rita, and I. S. Thokchom, "Hypoglycemic activity of Ficus hispida (bark) in normal and diabetic albino rats," Indian Journal of Pharmacology, vol. 36, no. 4, pp. 222-225, 2004.

[10] W. M. Koné, K. Kamanzi Atindehou, C. Terreaux, K. Hostettmann, D. Traoré, and M. Dosso, "Traditional medicine in North Côte-d'Ivoire: screening of 50 medicinal plants for antibacterial activity," Journal of Ethnopharmacology, vol. 93, no. 1, pp. 43-49, 2004.

[11] S. C. Mandal, B. Saraswathi, C. K. A. Kumar, S. M. Lakshmi, and B. C. Maiti, "Protective effect of leaf extract of Ficus hispida Linn. against paracetamol-induced hepatotoxicity in rats," Phytotherapy Research, vol. 14, no. 6, pp. 457-459, 2000.

[12] M. R. Saha, M. C. Shill, S. K. Biswas, and A. Faruque, "In-vitro antioxidant and cytotoxic activities of methanolic leaf extract of Ficus hispida Linn.," Stamford Journal of Pharmaceutical Sciences, vol. 3, no. 2, pp. 29-36, 2011.

[13] T. S. Shanmugarajan, M. Arunsundar, I. Somasundaram, E. Krishnakumar, D. Sivaraman, and V. Ravichandiran, "Cardioprotective effect of Ficus hispida Linn. on cyclophosphamide provoked oxidative myocardial injury in a rat model," International Journal of Pharmacology, vol. 4, no. 2, pp. 78-87, 2008. 
[14] T. Jahan, S. Shahreen, J. Banik et al., "Antinociceptive activity studies with methanol extracts of Ficus Hispida L.f. leaves and fruits in Swiss albino mice," Advances in Natural and Applied Sciences, vol. 5, no. 2, pp. 131-135, 2011.

[15] J. B. Harborne, Phytochemal Methods (A Guide to Modern Techniques to Plantanalysis), Chapman and Hall, London, UK, 3rd edition, 1984.

[16] W. C. Evans, Trease and Evan's Textbook of Pharmacognosy, Cambidge University Press, London, UK, 13th edition, 1989.

[17] E. Dussossoy, P. Brat, E. Bony et al., "Characterization, antioxidative and anti-inflammatory effects of Costa Rican noni juice (Morinda citrifolia L.)," Journal of Ethnopharmacology, vol. 133, no. 1, pp. 108-115, 2011.

[18] C.-C. Chang, M.-H. Yang, H.-M. Wen, and J.-C. Chern, "Estimation of total flavonoid content in propolis by two complementary colometric methods," Journal of Food and Drug Analysis, vol. 10, no. 3, pp. 178-182, 2002.

[19] J. El Hilaly, Z. H. Israili, and B. Lyoussi, "Acute and chronic toxicological studies of Ajuga iva in experimental animals," Journal of Ethnopharmacology, vol. 91, no. 1, pp. 43-50, 2004.

[20] B. A. Whittle, "The use of changes in capillary permeability in mice to distinguish between narcotic and nonnarcotic analgesics," British Journal of Pharmacology and Chemotherapy, vol. 22, no. 2, pp. 246-253, 1964.

[21] A. O. Jimoh, A. Chika, M. T. Umar, I. Adebisi, and N. Abdullahi, "Analgesic effects and anti-inflammatory properties of the crude methanolic extract of Schwenckia americana Linn (Solanaceae)," Journal of Ethnopharmacology, vol. 137, no. 1, pp. 543-546, 2011.

[22] S. Hunskaar and K. Hole, "The formalin test in mice: dissociation between inflammatory and non-inflammatory pain," Pain, vol. 30, no. 1, pp. 103-114, 1987.

[23] I. O. Ishola, A. J. Akindele, and O. O. Adeyemi, "Analgesic and anti-inflammatory activities of Cnestis ferruginea Vahl ex DC (Connaraceae) methanolic root extract," Journal of Ethnopharmacology, vol. 135, no. 1, pp. 55-62, 2011.

[24] N. B. Eddy and D. Leimbach, "Synthetic analgesics. II. Dithienylbutenyl- and dithienylbutylamines," The Journal of Pharmacology and Experimental Therapeutics, vol. 107, no. 3, pp. 385-393, 1953.

[25] T. Roome, A. Dar, S. Naqvi, and M. I. Choudhary, "Evaluation of antinociceptive effect of Aegiceras corniculatum stems extracts and its possible mechanism of action in rodents," Journal of Ethnopharmacology, vol. 135, no. 2, pp. 351-358, 2011.

[26] G. N. Silva, F. R. Martins, M. E. Matheus, S. G. Leitão, and P. D. Fernandes, "Investigation of anti-inflammatory and antinociceptive activities of Lantana trifolia," Journal of Ethnopharmacology, vol. 100, no. 3, pp. 254-259, 2005.

[27] C. A. Winter, E. A. Risley, and G. W. Nuss, "Carrageenininduced edema in hind paw of the rat as an assay for antiinflammatory drugs," Proceedings of the Society for Experimental Biology and Medicine, vol. 111, no. 3, pp. 544-547, 1962.

[28] W. Mequanint, E. Makonnen, and K. Urga, "In vivo antiinflammatory activities of leaf extracts of Ocimum lamiifolium in mice model," Journal of Ethnopharmacology, vol. 134, no. 1, pp. 32-36, 2011.

[29] J. B. Perianayagam, S. K. Sharma, and K. K. Pillai, "Antiinflammatory activity of Trichodesma indicum root extract in experimental animals," Journal of Ethnopharmacology, vol. 104, no. 3, pp. 410-414, 2006.
[30] R. Estrada-Reyes, M. Martínez-Vázquez, A. Gallegos-Solís, G. Heinze, and J. Moreno, "Depressant effects of Clinopodium mexicanum Benth. Govaerts (Lamiaceae) on the central nervous system," Journal of Ethnopharmacology, vol. 130, no. 1, pp. 1-8, 2010.

[31] J. Yau, U. N. Abdulmalik, A. H. Yaro, B. A. Chindo, J. A. Anuka, and I. M. Hussaini, "Behavioral properties of Balanites aegyptiaca in rodents," Journal of Ethnopharmacology, vol. 135, no. 3, pp. 725-729, 2011.

[32] K. Takagi, M. Watanabe, and H. Saito, "Studies of the spontaneous movement of animals by the hole cross test; effect of 2-dimethyl-aminoethanol and its acyl esters on the central nervous system," Japanese Journal of Pharmacology, vol. 21, no. 6, pp. 797-810, 1971.

[33] C. W. Dunnett, "A multiple comparison procedure for comparing several treatments with a control," Journal of the American Statistical Association, vol. 50, no. 272, pp. 1096-1121, 1955.

[34] A. G. Neto, J. M. L. C. Costa, C. C. Belati et al., "Analgesic and anti-inflammatory activity of a crude root extract of Pfaffia glomerata (Spreng) Pedersen," Journal of Ethnopharmacology, vol. 96, no. 1-2, pp. 87-91, 2005.

[35] M. Rabelo, E. P. Souza, P. M. G. Soares, A. V. Miranda, F. J. A. Matos, and D. N. Criddle, "Antinociceptive properties of the essential oil of Ocimum gratissimum L. (Labiatae) in mice," Brazilian Journal of Medical and Biological Research, vol. 36, no. 4, pp. 521-524, 2003.

[36] I. M. Villaseñor, A. P. Canlas, K. M. Faustino, and K. G. Plana, "Evaluation of the bioactivity of triterpene mixture isolated from Carmona retusa (Vahl.) Masam leaves," Journal of Ethnopharmacology, vol. 92, no. 1, pp. 53-56, 2004.

[37] C. A. Parada, C. H. Tambeli, F. Q. Cunha, and S. H. Ferreira, "The major role of peripheral release of histamine and 5hydroxytryptamine in formalin-induced nociception," Neuroscience, vol. 102, no. 4, pp. 937-944, 2001.

[38] Y.-F. Chen, H.-Y. Tsai, and T.-S. Wu, "Anti-inflammatory and analgesic activities from roots of Angelica pubescens," Planta Medica, vol. 61, no. 1, pp. 2-8, 1995.

[39] Y. Jinsmaa, Y. Fujita, K. Shiotani et al., "Differentiation of opioid receptor preference by [Dmtl] endomorphin-2-mediated antinociception in the mouse," European Journal of Pharmacology, vol. 509, no. 1, pp. 37-42, 2005.

[40] R. Arslan and N. Bektas, "Antinociceptive effect of methanol extract of Capparis ovata in mice," Pharmaceutical Biology, vol. 48, no. 10, pp. 1185-1190, 2010.

[41] F. A. Oliveira, C. L. S. Costa, M. H. Chaves et al., "Attenuation of capsaicin-induced acute and visceral nociceptive pain by $\alpha$ - and $\beta$-amyrin, a triterpene mixture isolated from Protium heptaphyllum resin in mice," Life Sciences, vol. 77, no. 23, pp. 2942-2952, 2005.

[42] R. K. N. Cuman, C. A. Bersani-Amado, and Z. B. Fortes, "Influence of type 2 diabetes on the inflammatory response in rats," Inflammation Research, vol. 50, no. 9, pp. 460-465, 2001.

[43] K. Seibert, Y. Zhang, K. Leahy et al., "Pharmacological and biochemical demonstration of the role of cyclooxygenase 2 in inflammation and pain," Proceedings of the National Academy of Sciences of the United States of America, vol. 91, no. 25, pp. 12013-12017, 1994.

[44] K. A. B. Simão Da Silva, A. F. Paszcuk, G. F. Passos et al., "Activation of cannabinoid receptors by the pentacyclic triterpene $\alpha, \beta$-amyrin inhibits inflammatory and neuropathic persistent pain in mice," Pain, vol. 152, no. 8, pp. 1872-1887, 2011. 
[45] K. Ashalatha, Y. Venkateswarlu, A. M. Priya, P. Lalitha, M. Krishnaveni, and S. Jayachandran, "Anti inflammatory potential of Decalepis hamiltonii (Wight and Arn) as evidenced by down regulation of pro inflammatory cytokines-TNF- $\alpha$ and IL-2," Journal of Ethnopharmacology, vol. 130, no. 1, pp. 167-170, 2010.

[46] M. A. Siraj, J. A. Shilpi, M. G. Hossain et al., "Anti-inflammatory and antioxidant activity of Acalypha hispida leaf and analysis of its major bioactive polyphenols by HPLC," Advanced Pharmaceutical Bulletin, vol. 6, no. 2, pp. 275-283, 2016.

[47] S. A. Sumi, M. A. Siraj, A. Hossain, M. S. Mia, S. Afrin, and M. M. Rahman, "Investigation of the key pharmacological activities of Ficus racemosa and analysis of its major bioactive polyphenols by HPLC-DAD," Evidence-Based Complementary and Alternative Medicine, vol. 2016, Article ID 3874516, 9 pages, 2016.

[48] W. C. Bowman and M. J. Rand, Textbook of Pharmacology, Blackwell Scientific, New York, NY, USA, 1980.

[49] B. A. Chindo, S. Amos, A. A. Odutola et al., "Central nervous system activity of the methanol extract of Ficus platyphylla stem bark," Journal of Ethnopharmacology, vol. 85, no. 1, pp. 131-137, 2003.

[50] R. M. Mansur, W. Martz, and E. A. Carlini, "Effects of acute and chronic administration of Cannabis satis and (-) 9-trans tetrahydro cannabinaol on the behaviour of rats in open field arena," Psychopharmacology, vol. 2, pp. 5-7, 1980.

[51] Y. Öztürk, S. Aydin, R. Beis, K. H. C. Başer, and H. Berberoglu, "Effects of Hypericum perforatum $\mathrm{L}$ and Hypericum calycinum $\mathrm{L}$ extracts on the central nervous system in mice," Phytomedicine, vol. 3, no. 2, pp. 139-146, 1996.

[52] O. T. Kolawole, J. M. Makinde, and O. A. Olajide, "Central nervous system depressant activity of Russelia equisetiformis," Nigerian Journal of Physiological Sciences, vol. 22, no. 1-2, pp. 5963, 2007.

[53] G. F. Aragão, L. M. V. Carneiro, A. P. F. Junior et al., "A possible mechanism for anxiolytic and antidepressant effects of alphaand beta-amyrin from Protium heptaphyllum (Aubl.) March," Pharmacology Biochemistry and Behavior, vol. 85, no. 4, pp. 827834, 2006.

[54] S. P. Fernández, C. Wasowski, L. M. Loscalzo et al., "Central nervous system depressant action of flavonoid glycosides," European Journal of Pharmacology, vol. 539, no. 3, pp. 168-176, 2006.

[55] P. P. Khairnar, J. C. Pawar, and S. R. Chaudhari, "Central nervous system activity of different extracts of Leucas longifolia Benth," Asian Journal of Pharmaceutical and Clinical Research, vol. 3, no. 4, pp. 48-52, 2010. 


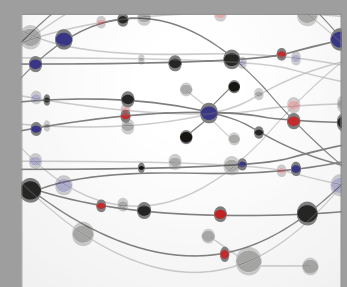

The Scientific World Journal
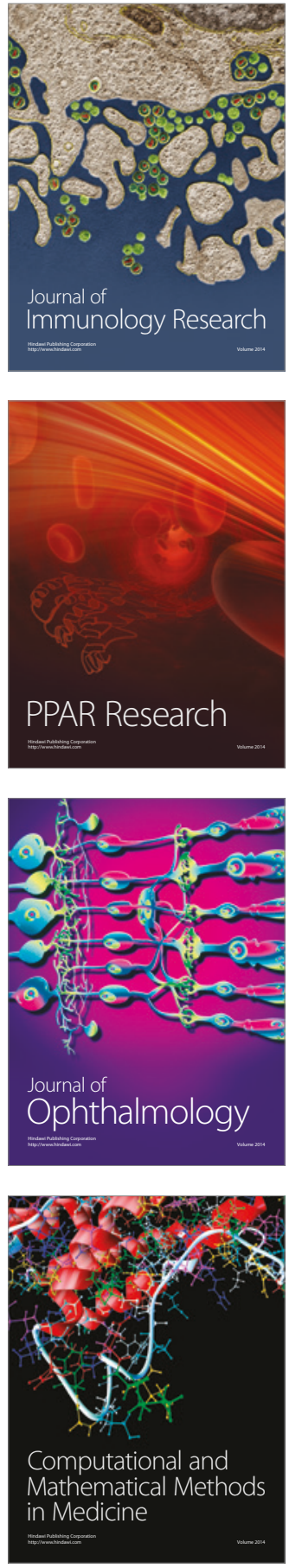

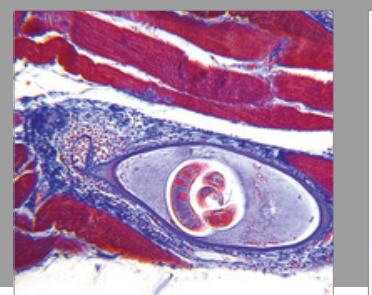

Gastroenterology Research and Practice
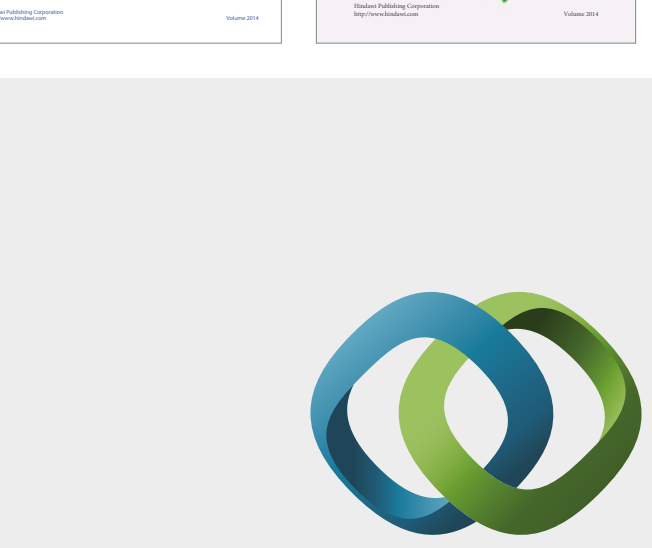

\section{Hindawi}

Submit your manuscripts at

https://www.hindawi.com
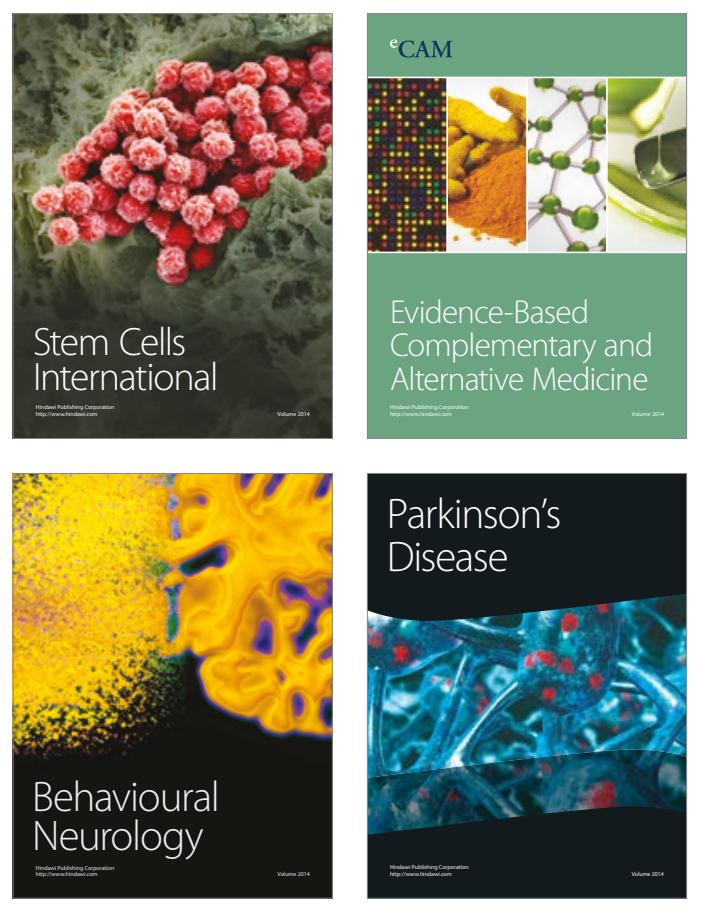
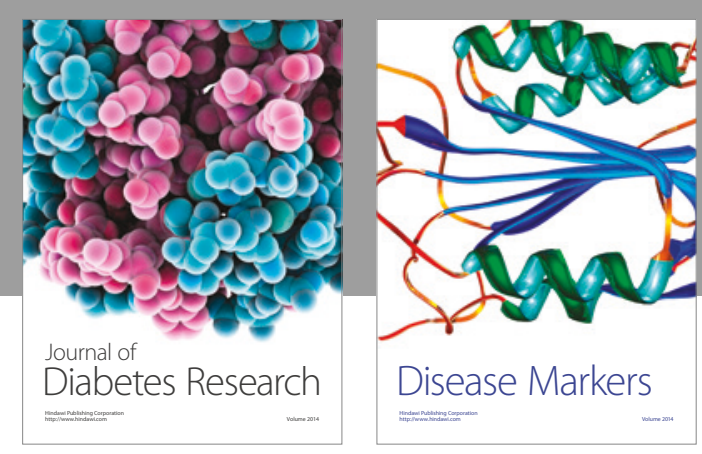

Disease Markers
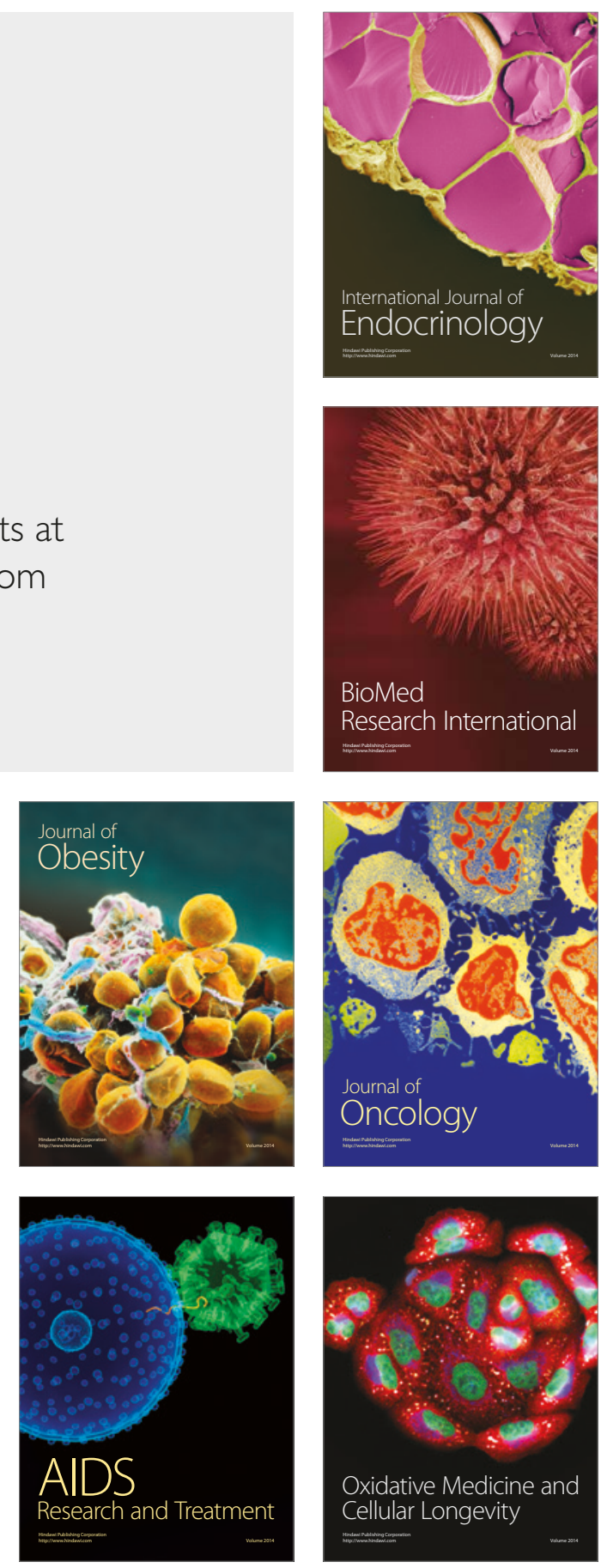